\title{
Politeness theory and relational work ${ }^{\mathbf{1}}$
}

\author{
MIRIAM A. LOCHER and RICHARD J.WATTS
}

\section{Abstract}

In this paper we briefly revisit politeness research influenced by Brown and Levinson's (1987) politeness theory. We argue that this research tradition does not deal with politeness but with the mitigation of face-threatening acts (FTAs) in general. In our understanding, politeness cannot just be equated with FTA-mitigation because politeness is a discursive concept. This means that what is polite (or impolite) should not be predicted by analysts. Instead, researchers should focus on the discursive struggle in which interactants engage. This reduces politeness to a much smaller part of facework than was assumed until the present, and it allows for interpretations that consider behavior to be merely appropriate and neither polite nor impolite. We propose that relational work, the "work" individuals invest in negotiating relationships with others, which includes impolite as well as polite or merely appropriate behavior, is a useful concept to help investigate the discursive struggle over politeness. We demonstrate this in close readings of five examples from naturally occurring interactions.

Keywords: politeness; impoliteness; face; relational work; facework

\section{Introduction}

Brown and Levinson's theory of politeness $(1978,1987)$ has given scholars an enormous amount of research mileage. Without it we would not be in a position to consider the phenomenon of politeness as a fundamental aspect of human socio-communicative verbal interaction in quite the depth and variety that is now available to us. The Brown and Levinson theory has towered above most others and has served as a guiding beacon for scholars interested in teasing out politeness phenomena from examples of human interaction. It provides a breadth of insights into human behavior which no other theory has yet offered, and it has served 
as a touchstone for researchers who have felt the need to go beyond it. Eelen (2001) places it on much the same level as other approaches to politeness that have been suggested by researchers in the field, e.g., Blum-Kulka et al. (1985), Blum-Kulka (1987, 1990), Janney and Arndt (1992), Ide (1989), Mao (1994), Gu (1990), Kasper (1990), Robin Lakoff (1973), Fraser (1990). But it is clearly in a class of its own in terms of its comprehensiveness, operationalizability, thoroughness and level of argumentation.

Why, then, has it been so frequently challenged? Does it need to be challenged at all if it provides such a solid basis for empirical research? There have of course been innumerable answers to these two questions, but we argue here that, solid and comprehensive as it is, Brown and Levinson's Politeness Theory is not in fact a theory of politeness, but rather a theory of facework, dealing only with the mitigation of facethreatening acts. The term "Politeness Theory" in itself is an over-extension of what participants themselves feel to be polite behavior. In addition, it does not account for those situations in which face-threat mitigation is not a priority, e. g., aggressive, abusive or rude behavior, nor does it cover social behavior considered to be "appropriate", "unmarked" or "politic" but which would hardly ever be judged as "polite". Brown and Levinson's framework can still be used, however, if we look at the strategies they have proposed to be possible realizations of what we call relational work.

In this paper we wish to propose that politeness is only a relatively small part of relational work and must be seen in relation to other types of interpersonal meaning. To make this clear we will define relational work in more detail and link it to Goffman's notion of "face" before looking at how other researchers have located politeness on a continuum of different types of relational work. We will then define politeness itself as a discursive concept arising out of interactants' perceptions and judgments of their own and others' verbal behavior. Using conversational data taken from situations in which we ourselves were participants, we shall argue that such perceptions are set against individual normative expectations of appropriate or politic behavior. They are in other words "marked" for each individual speaker/hearer.

\section{Relational work: A return to Goffman's notion of "face"}

Relational work refers to the "work" individuals invest in negotiating relationships with others. Human beings rely crucially on others to be able to realize their life goals and aspirations, and as social beings they will naturally orient themselves towards others in pursuing these goals. 
In indulging in social practice, they need not be aware of, and indeed are frequently oblivious of, their reliance on others.

One way of explaining our predisposition to act in specific ways in specific situations is to invoke the notion of frame (cf. Bateson 1954; Goffman 1974, 1981; Tannen 1993; Escandell-Vidal 1996; Schank and Abelson 1977). Tannen defines a frame as "structures of expectation based on past experience" (1993: 53), whereas Escandell-Vidal sees it as "an organized set of specific knowledge" (1996: 629). The central concept in Bourdieu's (1990) Theory of Practice is the habitus, which refers to "the set of predispositions to act in certain ways, which generates cognitive and bodily practices in the individual" (Watts 2003: 149). We consider both terms to account for the structuring, emergence, and continued existence of social norms which guide both verbal and non-verbal instances of relational work. Structuring may involve us in the exploitation of those norms and in forms of aggressive, conflictual behavior. We are not therefore arguing that relational work is always oriented to the maintenance of harmony, cooperation, and social equilibrium.

Looked at in this way, relational work comprises the entire continuum of verbal behavior from direct, impolite, rude or aggressive interaction through to polite interaction, encompassing both appropriate and inappropriate forms of social behavior (Locher 2004: 51). Impolite behavior is thus just as significant in defining relationships as appropriate/politic or polite behavior. In this sense relational work can be understood as equivalent to Halliday's (1978) interpersonal level of communication, in which interpersonal rather than ideational meaning is negotiated.

Following Goffman we argue that any interpersonal interaction involves the participants in the negotiation of face. The term "facework", therefore, should also span the entire breadth of interpersonal meaning. This, however, is rarely the case in the literature. Especially in accordance with Brown and Levinson's Politeness Theory, "facework" has been largely reserved to describe only appropriate and polite behavior with a focus on face-threat mitigation, at the exclusion of rude, impolite and inappropriate behavior. To avoid confusion and in favor of clarity we adopt "relational work" as our preferred terminology and conceptualize it in the form of the continuum in Figure 1.

In terms of individual participants' perceptions of verbal interaction, which is oriented to the norms established in previous interactions, a great deal of the relational work carried out will be of an unmarked nature and will go largely unnoticed (i. e., it will be politic/appropriate, column 2). Marked behavior, conversely, can be noticed in three ways. It will be perceived as negative if it is judged as impolite/non-politic/ inappropriate (column 1), or as over-polite/non-politic/inappropriate (column 4). We hypothesize that addressees' affective reactions to over- 


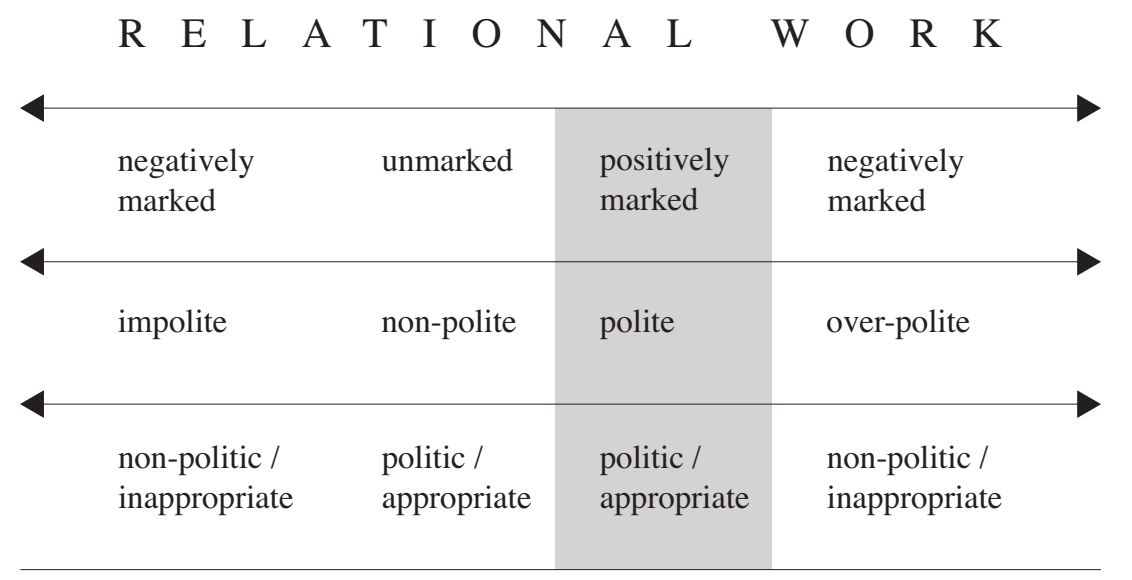

Figure 1. Relational work and its polite (shaded) version (adapted from Locher 2004: 90).

polite behavior will be roughly similar to their reactions to impolite behavior ${ }^{2}$. Positively marked behavior (column 3) will coincide with its being perceived as polite/politic/appropriate. In other words, polite behavior is always politic while politic behavior can also be non-polite. It is important to stress here that there can be no objectively definable boundaries between these categories if, as we argue later, politeness and related categories are discursively negotiated.

Central to the concept of relational work is Goffman's notion of face, which he has derived from Durkheim (1915). Goffman defines face as an image "pieced together from the expressive implications of the full flow of events in an undertaking", i. e., any form of social interaction ([1955] 1967: 31), and as "the positive social value a person effectively claims for [her/himself] by the line others assume [s/he] has taken during a particular contact" (1967: 5) ${ }^{3}$. It is therefore "an image of self delineated in terms of approved social attributes" (1967: 5). For Goffman face does not reside inherently in an individual, as would appear to be the case in interpretations of Brown and Levinson, but is rather constructed discursively with other members of the group in accordance with the line that each individual has chosen. So face is socially attributed in each individual instance of interaction, which implies that any individual may be attributed a potentially infinite number of faces. Faces, in other words, are rather like masks, on loan to us for the duration of different kinds of performance. Imagine a woman who, depending 
on the context she finds herself in, performs in the role of a Prime Minister, a mother, a wife, a gardener, a cook, etc. Whether or not the performance is accepted by other participants in the interaction will depend on their assignment or non-assignment of face, i. e., the mask associated with the performance.

Relational work thus comprises a more comprehensive notion of face than is offered in Brown and Levinson. But it will also lead to a more restricted view of politeness than is common in the literature. In order to show this, we will briefly review some of the more commonly used conceptualizations of politeness and then go on to outline what we understand to be the discursive approach.

\section{Politeness and its place within relational work in previous research}

Brown and Levinson have understood politeness to cover a different area in the continuum of relational work than what we are proposing in Figure 1. They see politeness as a complex system for softening facethreatening acts and only make a distinction between impolite and polite behavior. The ranking of their strategies implies that interactants have a choice between appearing more or less polite, or, conversely, impolite. Brown and Levinson, however, do not discuss a distinction in the level of relational work within politic/appropriate behavior, which we consider crucial for the understanding of politeness.

Many other researchers ${ }^{4}$ who have worked within the Brown and Levinson framework may have questioned Brown and Levinson's explanation of the motivation for using mitigating strategies, the usefulness of the variables proposed for the estimation of the weightiness of the risk of face loss, or their ranking of strategies with a stress on indirectness, but the general dichotomy between polite and impolite behavior without any room for appropriate/politic and non-polite behavior remains mostly unchallenged in their theoretical discussion of the concept of politeness.

The same is true for Fraser's (1975, 1990; Fraser and Nolen 1981) approach to politeness. Fraser (1990: 233) maintains that "[p]oliteness is a state that one expects to exist in every conversation; participants note not that someone is being polite - this is the norm - but rather that the speaker is violating the [conversational contract]". The breaches of norms which Fraser discusses to support his argument are mainly negative ones, i. e., they underline the distinction between impolite/appropriate and appropriate/politic/polite behavior, but do not shed any light on whether there is a distinction between polite and merely appropriate behavior. In fact, Fraser treats everything that is not impolite as polite. This dichotomy is also taken on board by Escandell-Vidal (1996) and Meier (1995a, b). The latter, however, pleads for replacing the term "po- 


\begin{tabular}{|c|c|c|}
\hline Researchers: & $\begin{array}{l}\text { Mentioned } \\
\text { sporadically } \\
\text { in the } \\
\text { literature. }\end{array}$ & $\mathrm{F} A \mathrm{C}$ W O R K \\
\hline $\begin{array}{l}\text { Brown and Levinson } \\
\text { (1987), Lakoff (1973), } \\
\text { Leech (1983), Fraser } \\
\text { (1990), Sifianou (1992), } \\
\text { Meier (1995), Held } \\
\text { (1995), Holmes (1995), }\end{array}$ & $\begin{array}{l}\text { impolite }^{5} \\
\text { inappropriate }\end{array}$ & $\begin{array}{c}\text { polite } \\
\text { appropriate }\end{array}$ \\
\hline
\end{tabular}

Figure 2. Politeness in previous research (simplified).

lite" with "appropriate", i.e., with "socially acceptable" behavior (1995b: 387).

Lakoff (1973) and Leech (1983), whose discussion of politeness can be labeled as constituting "a social maxim approach", also make the distinction between polite and impolite behavior. In their frameworks, they propose conversational maxims which interactants will orient themselves to. Lakoff's (1973) rules of politeness are (1) Don't impose, (2) Give options and (3) Make A feel good; Be friendly. Leech (1983) uses Grice's Cooperative Principle (1975) and adds the Politeness Principle which consists of six maxims that aim at "strategic conflict avoidance". There is no mention of a marked uptake of polite utterances. Figure 2 visualizes in a simplified way the dichotomy of the research approaches mentioned.

Watts (1989, 1992, 2003), Kasper (1990), and Locher (2004) have argued for making further distinctions within appropriate behavior as is evident in Figure 1. We believe that there is a difference between, on the one hand, non-polite, yet appropriate/politic behavior, and, on the other hand, appropriate/politic and polite behavior. In the next section we shall explain our position in more detail.

\section{Politeness as a discursive concept}

In Watts et al. (1992) a distinction was made between "first order politeness" and "second order politeness", although these terms were not explicitly developed at the time. The distinction was taken up by Eelen 
(2001) and further developed in Watts (2003) and Locher (2002). By first order politeness (politeness1) we understand how participants in verbal interaction make explicit use of the terms "polite" and "politeness" to refer to their own and others' social behavior. Second order politeness (politeness2) makes use of the terms "polite" and "politeness" as theoretical concepts in a top-down model to refer to forms of social behavior. The rationale for making this distinction was that lay references to politeness, i.e., forms of verbal behavior that non-linguists would commonly label "polite", "courteous", "refined", "polished", etc., rarely corresponded to definitions of politeness in most of the canonical literature until the beginning of the 1990s.

Let us exemplify the dangers involved in focusing uniquely on politeness 2 by taking a closer look at one interpretation which takes it to correlate with the degree of indirectness in speech acts. Consider examples (1) and (2):

(1) Lend me your pen.

(2) Could you lend me your pen?

The assumption is made in this approach to politeness2 that (2) would be perceived by native speaker informants as more polite than (1). But it should be clear that any shift in the social context of the interaction will lead to significant shifts in those possible perceptions of politeness. Most people would not feel (2) to be a polite utterance, but merely to be appropriate in a given social context. Example (1) may be perceived by many people to be too direct, but not necessarily impolite. Imagine a husband and wife who might use either (1) or (2) in a wide variety of social contexts and not find (2) more polite than (1) but find both (1) and (2) equally appropriate.

Imagine receiving the "request" as in (3):

\section{(3) Oi! Pen!}

Without contextualizing (3), a native speaker's immediate reaction to the utterance is likely to be that it is "rude" or "impolite". However, if the relationship between speaker and addressee is such that this form of behavior is interpretable as good-humored banter, it is likely to be perceived as perfectly appropriate to the social situation.

Now imagine the following request:

(4) I wonder whether you would be so very kind as to lend me your pen?

In many social contexts (4) is clearly inappropriate and is likely to be classified as over-polite, ironic, etc. Indeed, there may be a large number 
of native speakers of English who would react negatively to (4) but still classify it as "polite", thus displaying a negative orientation towards politeness.

From this brief consideration of the weaknesses arising from a correlation of indirectness with politeness2, we can draw two conclusions. Firstly, native speaker reactions to what is commonly thought of in the literature as realizations of politeness are likely to vary across the whole range of options within relational work given in Figure 1. It is quite conceivable that individual reactions may vary even when the social context in which the "polite" utterance occurs is kept constant ${ }^{6}$. Secondly, and as a consequence of the first point, no linguistic expression can be taken to be inherently polite (e.g., Holmes 1995; Mills 2003; Watts 2003; Locher 2004).

We therefore see little point in maintaining a universal theoretical notion of politeness when there is discursive dispute about what is considered "rude", "impolite", "normal", "appropriate", "politic", "polite" or "over-polite" behavior in the various communities of practice in which these terms are actually used. We consider it important to take native speaker assessments of politeness seriously and to make them the basis of a discursive, data-driven, bottom-up approach to politeness. The discursive dispute over such terms in instances of social practice should represent the locus of attention for politeness research. By discursive dispute we do not mean real instances of disagreement amongst members of a community of practice over the terms "polite", "impolite", etc. but rather the discursive structuring and reproduction of forms of behavior and their potential assessments along the kind of scale given in Figure 1 by individual participants. As we pointed out above, there may be a great deal of variation in these assessments.

For this reason, it is necessary to focus on the entire range of relational work, much of which will consist of forms of verbal behavior produced by the participants in accordance with what they feel - individually to be appropriate to the social interaction in which they are involved. Much of the time - but by no means always - they will be unconscious of an orientation towards social frames, social norms, social expectations, etc. They will be reproducing forms of behavior in social practice in accordance with the predispositions of their habitus (Bourdieu 1990) and will thus be using what Bourdieu calls their "feel for the game". We have called this unmarked, socially appropriate behavior "politic behavior", which may or may not be strategic.

In the following section we will tease out what we, as participants in the social interaction analyzed, felt to be co-participants' perceptions of the kind of relational work being carried out. This will necessitate a close focus on salient verbal behavior of various kinds which participants may 
have perceived as "more than politic" or "less than politic", i. e., as "polite", "over-polite" or "impolite", even though they may not use these terms explicitly. We prefer to use an interpretive approach towards instances of verbal interaction rather than to ask the participants themselves how they felt about what they were doing. This latter method of accessing participants' perceptions of politeness, like those in which informants are asked to react to real or intuited examples of interaction, is flawed precisely because they are being asked to evaluate consciously along a "polite-impolite" parameter which might not correspond to what they perceived at the time.

\section{Relational work in naturally occurring speech}

The theory of relational work presented in this paper posits that social behavior which is appropriate to the social context of the interactional situation only warrants potential evaluation by the participants (or others) as polite or impolite if it is perceived to be salient or marked behavior. This logically entails that we are able to specify the "appropriateness" of the interaction under analysis before such salient behavior can be identified. We argue that appropriateness is determined by the frame or the habitus of the participants (see above) within which face is attributed to each participant by the others in accordance with the lines taken in the interaction.

To test the efficacy of locating examples of politeness within this framework, we shall analyze in some detail five conversational extracts, the first taken from Watts' family data, the others from Locher's data of a dinner conversation between a family and their friends. Our overall intention is to demonstrate that much of what has commonly been thought of as "politeness" may in fact be perceived by participants not as politeness1, but rather as the kind of behavior appropriate to the current interaction, i. e., what we refer to as "politic behavior". In order to make this point, we present a reading of a conflictual situation within a family in which face-threat mitigation is interpretable as neither polite nor impolite, a situation in which forms of politic behavior dominate, two instances of complimenting, one of which is open to a polite interpretation and the other not, and we will end with a situation in which "(im)politeness" is discussed by the participants themselves (i. e., an example of Eelen's metapragmatic politeness [Eelen 2001]) ${ }^{7}$.

The following extract is taken from Watts' collection of family discourse. The recording was made in 1985, two years prior to the emigration to Australia of R's mother (B) and stepfather (D). R and his wife A were on a visit to B and D at their home in Cornwall. B had recently returned from a visit to her cousins in Australia, which she undertook 
with her daughter. At age 59, D was one year away from retirement from the Civil Service, for which he had been working for approximately 15 years. Since he had lost his pension from earlier employment at a bank in London, D was expecting a very low pension indeed, which would have meant either applying for Supplementary Benefit or starting up his own business.

B's strategic goal, her line in the interaction, is to persuade D to consider emigrating to Australia. Although this is never mentioned explicitly throughout the entire conversation, it is known to all the participants. The intonation patterns produced by $\mathrm{B}$ in (5) and her general tone of voice indicate that she has taken on the role of the worried wife, disturbed by the prospect of a considerable cut in their overall income and the possibility of needing to avoid poverty by applying for Supplementary Benefit. She can also be expected to challenge D's proposed solutions on the basis of what she considers to be the panacea for all their problems - emigration to Australia.

The relational work is particularly delicate and fraught with potential conflict, with D wanting to stay in Britain but not knowing how to retain their standard of living after age 60 and $\mathrm{B}$ wanting to put a case for considering the other option of a move to Australia, but not daring to mention this openly. $\mathrm{R}$ and $\mathrm{A}$ are aware of these two conflicting lines and are equally aware of the potential for conflict involved. Although this is not evident in (5), R's line can be defined as giving D and B an opportunity to air this problem and, wherever possible, to make alternative solutions or evaluate those made by B and D. A's line is similar to $\mathrm{R}$ 's except that, as a stranger to the British welfare system, she acts more as a sympathetic, supportive listener:

(5) 1 D: so I've been thinking of ways and means of how I can earn a crust of bread at age ${ }^{\wedge}$ sixty.

$\rightarrow \quad 2 \quad(7.5)$

3 R: it's ^crazy.

$\rightarrow \quad 4$ B: and what ideas have you got?

5 I mean -

6 D: I ^told you.

7 I told you what ideas I got.

$\rightarrow \quad 8 \quad(2.0)$

$\rightarrow 9$ B: they don't seem feasible to ${ }^{\wedge} \mathrm{me}$.

10 D: alright,

11 well they ^don't.

12 we'll have to wait and ^see.

$\rightarrow 13 \quad$ (1.7)

$\rightarrow \quad 14$ B: well it's- it's- it's- it's - 
15 to ^my mind saying <Q Well we'll have to wait and see Q $>$

16 is- is rather- is- is rather negative and leaving it rather late.

$17 \quad$ (1.0) I mean -

$\rightarrow \quad 17 \quad(4.2)$

18 D: brr a ha ha haa ((IRONIC IMITATION OF LAUGHTER))

$\rightarrow \quad 19 \quad(4.5)$

$\rightarrow \quad 20$ D: well got any 'ideas?

$21 \mathrm{R}: \quad \mathrm{Xxx}[\mathrm{xxX}>$

22 B: [well it's just a/ I mean, (2.9)

23 I don't know.

24 I mean, (0.7) what- what can- what can you do?

25 (0.6) you're not likely to get anybody to ^employ you.

$26 \quad(1.0)$

27 D: true.

$28 \quad(0.6)$

29 B: and it's ^very ^very difficult to set up (.) a business on your own without :er: a fair amount of capital behind you.

30 look how many (.) one-man businesses go down the drain.

31 D: yes I would know that in ^my job.=

$\rightarrow \quad 32 \mathrm{~B}:=$ of $^{\wedge}$ course y[ou do.

33 R: $\quad$ [I see.

34 B: so (0.6) :erm: what are you being optimistic about?

. [and saying that we'll wait and see because -

35 D: [I've never been -

36 D: I've never been a ^pessimist.

What did the participants perceive to be appropriate, or politic, behavior in the verbal interaction from which extract (5) was taken? The line that $\mathrm{D}$ is assumed (by D, B, and A) to be taking in (5) is that of a resource person giving information on his own personal predicament with respect to his expected pension at age 60 . R, B, and A have placed that topic on the agenda of the conversation before extract (5) begins, and it has been accepted by $\mathrm{D}$. He can therefore be expected to raise possible solutions for discussion. But D does not go into this topic without knowing perfectly well that B has already heard some of the suggestions he has made and that she is not convinced that they will be effective. In addition, he also knows that B has just returned from Australia full of praise for its climate, the lower cost of living, the re-establishment of connections with her extended family, etc. Conversely, he himself is not convinced that emigration to Australia is the solution. 
The purpose of the overall interaction from which (5) has been taken is to openly air problems and invite different positions with respect to them. There is thus an orientation towards a conflict frame in which we can expect, at least in the contributions by D and B, open criticism, accusation, recrimination, indignation, etc. This is the kind of politic behavior that all the participants expect. It will allow them to attack one another, which entails the notion of face-threatening. Extract (5) is taken from a section of the overall interaction in which the tension between $D$ and $\mathrm{B}$ becomes very clear. This is indicated by the long silences between turns at lines 2, 8, 13,17, and 19. Either $\mathrm{R}$ or A could have intervened, particularly at lines 2,17 , and 19 . But the conflict is between D and $\mathrm{B}$, and even though the lines taken by $\mathrm{R}$ and $\mathrm{A}$ would have ratified some form of intervention, they choose to let D and B continue. Silence thus becomes a salient and very meaningful mode of communication in (5) (cf. Watts 1997). We argue that it is precisely these silences that characterize the conflictual politic behavior typical for this family.

So what is going on here? We would like to argue that what we are witnessing is a struggle between D and B to convince the other of the strength of their respective positions, even though B's position is not made explicitly clear in the whole interaction. Let us focus on lines 29-36:

(6) 29 B: and it's ${ }^{\wedge}$ very ${ }^{\wedge}$ very difficult to set up (.) a business on your own without :er: a fair amount of capital behind you.

30 look how many (.) one-man businesses go down the drain.

31 D: yes I would know that in ${ }^{\wedge}$ my job. $=$

$\rightarrow 32 \mathrm{~B}:=$ of $^{\wedge}$ course y[ou do.

33 R: $\quad$ [I see.

34 B: so (0.6) :erm: what are you being optimistic about? . [and saying that we'll wait and see because -

35 D: [I've never been -

36 D: I've never been a ^pessimist.

In line $29 \mathrm{~B}$ begins to develop a position from which she will argue that the idea of staying in Britain is weaker than that of emigrating. She immediately supports this position in line 30 . D actually confirms her argument by referring to his own work experience as a civil servant responsible for assessing claims for Supplementary Benefit and family support, implying that, if he did start up in business, he would be well aware of these dangers. B immediately latches her utterance of course you do in line 32 onto his and then proceeds in line 34 to challenge his argument. 
What, therefore, is the status of the utterance of course you do in line 32? If its intention is to mitigate face-threatening, the face-threats have already been committed by virtue of her previous contributions. Even if the utterance were open to a polite reading, she cancels it out in the challenge in line 34. The face-mitigating effect of of course you do does not leave the utterance open to a polite reading, and it is clearly not taken as such in the interaction. Although we have witnessed several challenges in extract (5), we have not been able to discover any strategies that were meant unequivocally to mitigate face-threatening. In the Brown and Levinson framework, however, we would expect mitigation to occur. We have thus shown that the politic behavior for conflictual interaction in this particular family allows for non-mitigating, challenging behavior. It is not perceived as impolite, but is likely to be evaluated by the interactants as appropriate, non-polite and politic behavior (cf. Figure 1).

The extracts taken from Locher's data are part of the transcription of a dinner conversation among family and friends in Philadelphia, recorded in 1997. There are seven people involved. Anne and John are the hosts; they are in their forties. John is an engineer and Anne is a graphic designer. Debbie is their teenage daughter. This family settled in the United States 15 years before the recording and originally comes from Turkey. Roy and Kate are both in their sixties. They are married, are academics, and have lived in the United States all their lives. Roy is John's cousin. Steven, aged 38, is a doctor and American. He is Kate's nephew. Miriam, who is Swiss, is Kate's and Roy's close friend and has met all the other interactants before ${ }^{8}$. The dinner takes place at Anne and John's house in the evening.

In (7) we can see a typical situation such as can happen time and again at a dinner table. There is an ongoing conversation, in our case with Kate as the main narrator (11. 1-11), which is then interrupted by action related to the process of eating; in our extract the fruit tarts for dessert are brought into the dining room (1.12). It is of interest to see how interactants manage these shifts with respect to relational work. In what follows, we shall focus on Kate and Anne:

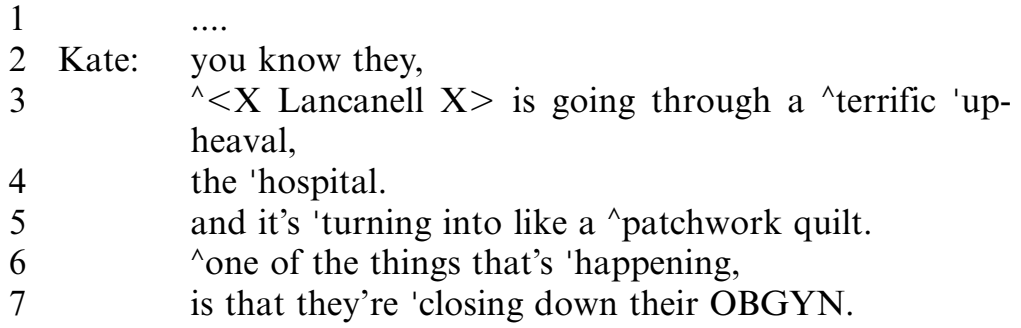




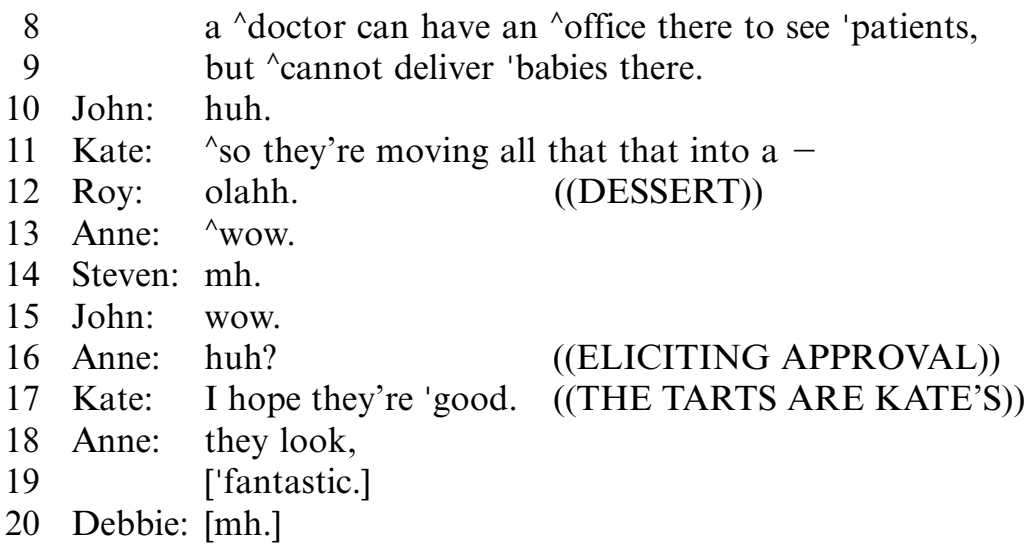

In lines 10-20 Kate has relinquished the floor and everybody voices his or her appreciation of the dessert that is being served. However, in the continuation of this episode, Kate attempts to take up the thread of her narrative again (1. 21 in (8) below). She marks this by saying anyway. This move is not successful because Anne sees the need to interrupt Kate: she has not quite finished her duties as hostess yet, which require that she find out who would like coffee or tea with the dessert. Anne first says [uh a 'question] before you, (1.23) and then explicitly asks for permission to interrupt ('may I interrupt; 1.25). Both times Kate gives Anne permission to fulfill her duties as hostess by saying yes (1l. 24, 26):

(8) 18 Anne: they look,

19 ['fantastic.]

20 Debbie: [mh.]

$\rightarrow 21$ Kate: 'anyway uh,

22 [the ${ }^{\wedge}$ cancer center,]

$\rightarrow 23$ Anne: [uh a 'question] before you,

$\rightarrow 24$ Kate: ${ }^{\wedge}$ yes.

$\rightarrow 25$ Anne: 'may I interrupt.

$\rightarrow 26$ Kate: [^yes.]

27 Anne: [^coffee?]

28 Kate: [[no thank you,

29 'not for me.]]

30 Anne: [[ $<\mathrm{X}$ coffee $\mathrm{X}>$ coffee?]

31 Miriam: I'd [like $<X$ coffee $X>$.]

32 Kate: [^how about] 'you Steven,

33 some coffee?

34 Anne: coffee? 


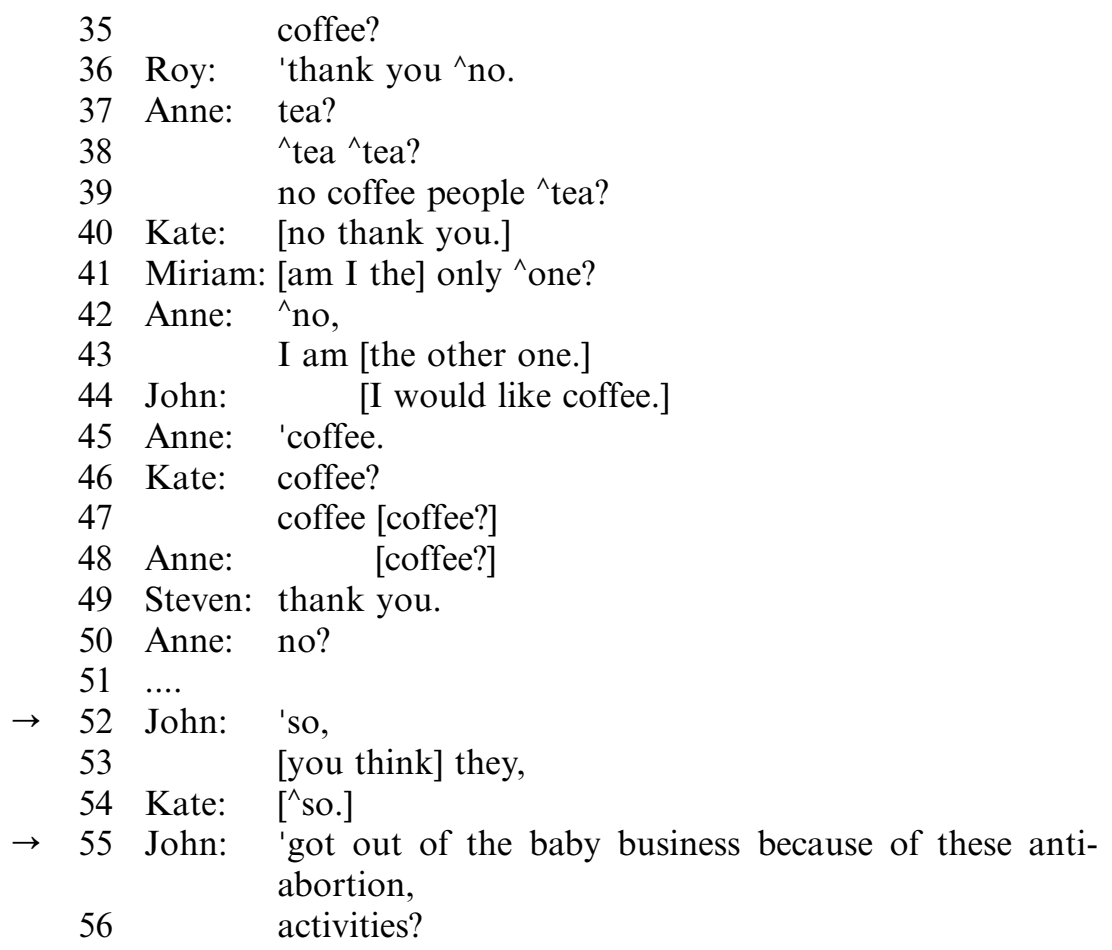

After Anne gets the okay from Kate to proceed, she addresses everybody in turn with the offer of coffee or tea. Notice that Kate even participates in this round of questions (11. 32-33, 46-47). Once the round is completed, there is a brief silence before John leads the way back to Kate's narrative with a question addressed to her (1. 52). This confirms her once again as the main narrator.

This brief episode shows that the appropriate level of relational work is important for smooth interaction. Anne has taken care to indicate to Kate that the interruption is not meant to be offensive but that the interactional framework, her duties as hostess, require her to interrupt. Kate, in turn, has acknowledged the importance of Anne's role, and they have therefore mutually confirmed their respective roles as narrator and hostess. In a non-aggressive framework of interaction such as the present, the level of relational work invested seems to be politic and appropriate. Despite the fact that we even have a question with a modal asking for permission to interrupt, we cannot claim that this constituted politeness in itself. Nevertheless, the smooth transitions from orientation to a narrative framework to a serving framework and back show that care is taken to take each other's face into consideration to an extent that al- 
lows us to make the assumption that this display of politic behavior may be judged as more than just politic, i. e., is open to a polite interpretation.

The following two extracts ([9] and [10]) are focused on the speech event of complimenting, which is often defined in the literature as inherently polite. The compliments in (9) are delivered at the end of the dinner. The group had been talking about each other's preferences for certain spices, when Kate compliments Steven on his cooking (1. 1). This is met with a downtoner from Steve $(n a h, 1.2)$ and a confirmation from Roy (yeah, 1. 3). In lines 5-18, the compliments are addressed to Anne, who is the cook of the present dinner, and it is these that we shall focus on here:

(9) 1 Kate: 'Steven is a ${ }^{\wedge}$ terrific ${ }^{\wedge}$ chef.

2 Steven: nah.

3 Roy: yeah.

((DISAGREEMENT))

4 Steven: <X it's a lot of 'effort. X>

$\rightarrow 5$ Roy: but ${ }^{\wedge}$ not as good as ${ }^{\wedge}$ this.

$\rightarrow 6$ Steven: 'this is 'very good.

7 Anne: which one?

$\rightarrow \quad 8$ Kate: ${ }^{\wedge}$ your [^dinner was ${ }^{\wedge}$ fantastic.]

$\rightarrow 9$ Anne: $\quad\left[\right.$ Kate ${ }^{\wedge}$ please] for heavens sake $<@$ come on Kate $@>$.

$\rightarrow 10 \quad$ ^just a ^ bird.

$\rightarrow 11$ Kate: $\quad .{ }^{\wedge}$ nice birds.

$\rightarrow 12 \quad$.. well this was ^delightful.

$\rightarrow 13$ Anne: well ^thank ^you.

$\rightarrow 14$ Kate: just ^delightful.

$\rightarrow 15$ Miriam: ${ }^{\wedge}$ thanks very ${ }^{\wedge}$ much. $\quad$ Steven: this ${ }^{\wedge}$ person who came out -

$\rightarrow 16$ Anne: you're ^very welcome I'm glad - a week or two ago about,

18 I re about some $<\mathrm{X} \mathrm{X}$ genetic X X $>$.

19 Kate: [^I've known her since she was ${ }^{\wedge}$ four ${ }^{\wedge}$ years old.

20 when she was ^tiny little girl.]

21 Miriam: [@@@]

22 Anne: $[\mathrm{I}<\mathrm{X}$ XXX X $>$

23 'I'm trying to think,

24 really,]

Roy, Steven, Kate and Miriam all compliment and thank Anne, who first rejects the praise (Kate ^please for heavens sake $<@$ come on Kate @ >. ${ }^{\wedge}$ just $a^{\wedge}$ bird. 11. 9-10) and then accepts (well ${ }^{\wedge}$ thank $\wedge^{\wedge}$ you. 1. 13). In 
lines $15-18$, Steven unsuccessfully starts a new topic on genetic research while Miriam and Anne are still engaged in an exchange and acceptance of thanks. After this, the round of compliments is finished and a new conversational topic is started. We argue that the participants are following the line expected of them in complimenting the cook, who in turn follows the line expected of the hostess in at first rejecting and then accepting the compliments. They are, in other words, producing appropriate, or politic, behavior. In fact, it is so much part of the expected politic behavior at a dinner party that it could scarcely be left out.

Extract (10) occurs at the beginning of the evening and represents compliments which are marked, i. e., they give more than they need to give. The interactants are gathered in the sitting room, having snacks before the main dinner. Debbie, the daughter of the hosts Anne and John, entered the room only a short time before. The conversation splits in two, with Anne and Steven engaging in the discussion of the similarity of Anne's and her daughter's voice and Kate, Roy, and Debbie engaging in an exchange of greetings and compliments. In our discussion we shall focus on the second strand of interaction as given in (10):

(10) 1 John: $<$ X it's totally totally [I I I I] XXX XX. X $>$

2 Kate: [^perfect.]

3 Roy: 'nice to see you 'how are you?

$\rightarrow \quad 4 \quad$ 'nice to ^see you.

5 Debbie: 'nice to see you $<\mathrm{X} \mathrm{XX.} \mathrm{X>}$

$\rightarrow \quad 6$ Kate: ${ }^{\wedge}$ God does she look 'gorgeous.

7 Roy: here you go 'lady.

8 Debbie: thank you.

$\rightarrow 9$ Kate: 'Deb?

$\rightarrow 10 \quad$ ^everytime I see you,

$\rightarrow 11 \quad$ you're ${ }^{\wedge}$ more 'beautiful.

$\rightarrow 12 \quad$ and ${ }^{\wedge}$ I don't know how much more ${ }^{\wedge}$ beautiful you can get?

13 Miriam:@@.

$\rightarrow 14$ Kate: it's ^unbelievable.

$\rightarrow 15 \quad\left[\right.$ it ${ }^{\wedge}$ doesn't] ${ }^{\wedge}$ stop does it.

16 Debbie: [thank you.]

17 thankyou@@.

$\rightarrow 18$ Kate: it ^doesn't ^stop.

19 Debbie:@@

$\rightarrow 20$ Kate: she 'looks absolutely ^gorgeous.

21 Steven: you got on the 'phone and said ${ }^{\wedge}$ Debbie.

22 and ${ }^{\wedge} \mathrm{I}$ thought,

((ADDRESSING DEBBIE)) 
that ${ }^{\wedge}$ you were 'expecting a call from ${ }^{\wedge}$ her and you said her name because I,

In line 3, Roy greets Debbie as the last person in the round. He emphasizes his happiness to see her by repeating 'nice to ${ }^{\wedge}$ see you with a salient stress on see you. This shifts Kate's attention once again to Debbie. In the ensuing turns she compliments Debbie on her beauty several times using an exaggerated, hence marked stress pattern. The compliments are greeted by laughing acceptance on Debbie's side (thank you@@, 11. 16$17,19)$. In this passage they function as strategies for relational work that aim at making a participant feel good (Lakoff 1973), i. e., in this case to show Debbie that her presence is valued. Roy marks this by repeating and emphasizing his utterance. Kate makes sure that her compliments are heard by repeating them and intensifying them (11. 9-12, 14-15; it ${ }^{\wedge}$ doesn't ${ }^{\wedge}$ stop, 1. 18; she 'looks absolutely ${ }^{\wedge}$ gorgeous, 1. 20). The humor in Kate's contributions also makes it easier for Debbie to accept the compliments.

Contrary to the previous example, if we imagine Kate not having uttered the compliments at all, the ongoing interaction would not have been any the worse for it. It is not that this imagined absence would have turned the interaction into impolite or rude behavior. Kate's contribution, however, especially in its emphatic and enthusiastic form seems to be a marked case of relational work. Whether the participants see the compliments as realizations of politeness remains debatable, but it is clearly open to a polite interpretation by the participants concerned. The analysis of (9) and (10) indicates that compliments as such are not inherently politeness markers.

In extract (11) we have one of the rare instances in our data in which interactants actually engage in a discussion of the concept of (im)politeness. After Roy talks about his colleague's greatest compliment being $I$ 'can't find anything 'wrong with it [= our work] yet (1. 3), Anne tells the story of a customer's husband who did not behave according to her expectations. While she expected a clear confirmation that her work as a graphic designer meets the requirements, she only received silence, which the customer's husband interpreted as agreement (did I say I didn't like it? 1. 18).

$\begin{array}{lll}\text { (11) } 1 & \text { Roy: } & \text { so but the the 'biggest ^ }{ }^{\wedge} \text { compliment, } \\ 2 & & \text { he can ever 'pay to some work we're doing is }<\mathrm{Q} \text { well I, } \\ 3 & & \text { I } \text { can't find anything 'wrong with it yet. } \mathrm{Q}>\text {. } \\ 4 & \text { All: } & @ @[@ @ @ @] \\ 5 & \text { Roy: } & {[<\mathrm{X} \text { and that XX X }>]}\end{array}$ 
8 John:@@@@@]

9 Anne: [@@ I had a client like that $<\mathrm{X}$ the one I hate?

$\mathrm{X}>$ ]

10 Kate: yeah.

11 Anne: and uh,

12

16 Kate:

$\rightarrow 17$ Anne: .. I wait 'politely wait 'politely 'nothing is coming out so I say $<@$ finally,

20 Kate:
.. the 'husband came and, the 'ad is on the computer is 'finished is 'ready to go to the 'printer.

.. 'no 'reaction.

.. I 'have to 'have that 'okay to send it to the [^printer.]

[right.] so 'basically did you 'like it or 'not @>>.

$\ldots<\mathrm{Q}$ did I say [I didn't like it?] $\mathrm{Q}>$

[@@@ $<@$ oh 'God. @ >

What is interesting in (11) for our discussion is Anne's comment that she met the customer's silence with what she labels "polite" behavior, which in turn is silence before she verbalizes her concern (I wait 'politely wait 'politely 'nothing is coming out so I say <@ finally, 1. 17)'. Comments like these must have been what Fraser (1990) had in mind when he said that people notice the absence of politeness rather than its presence. The continuation of (11) in (12) shows, however, that people are aware of the discursive nature of the norms against which they judge behavior:

(12)21 Anne: @@ $<@$ so apparently that was $<\mathrm{X}$ him XX X $>@>$.

22 Miriam: [@@]

$\rightarrow \quad 23$ Anne: [but] you have to 'translate those things right?

24 Miriam: uh-hu.

$\rightarrow 25$ Kate: you you learn to uh,

26 to 'try and read other people's,

27 how would I say 'temperature of 'enthusiasm.

28 Anne: yeah 'exactly.

29 Kate: you see ${ }^{\wedge}$ mine is $b-$

$30{ }^{\wedge}$ my thing goes like 'this.

31 Anne: oh Kate 'we know 'yours.

32 Kate: you know 'mine -

33 [and this -]

34 Roy: [yours doesn't] go like that yours is just always 'pit/ ^bumml. 
35 Anne:@@@@@

36 X, male: $<$ XXXX X

37 Roy:@@@@@

38 Kate:@@

39 .. it's so 'interesting though you know,

40

41

42

${ }^{\wedge}$ Roy is good about that sometimes Roy says he -

(1)

43

44

45

Steven: yeah. 'people give 'seminars and 'nobody 'says anything. if 'somebody does a good job ^I 'compliment them I'm thrilled you know?

46 Roy: .. well ^I don't think they're 'blasé they're just,

'some people are just so uh, .. aren't they blasé? there's a culture out these days to think that it's not, it's not 'cool to tell somebody it was good.

Anne uses the word translate to refer to the process of understanding other people's ways of interacting and ways of communicating values (1. 23), and Kate describes it as a learning process (11. 25-27). After a brief intermezzo in which Kate's unmistakable way of making her enthusiasm clear is discussed, Roy uses the word culture to explain why people differ in how they wish to express their approval (11. 46-48).

Finding precisely the "right" way to express approval, enthusiasm or criticism is an interactional achievement that depends on hitting just the right level of relational work which is hopefully the one that corresponds best to the addressee's own expectations of adequate behavior. In extracts (11) and (12) we can clearly see that interactants are quite aware of this difficulty, i. e., that they are aware of the discursive nature of politeness.

\section{Conclusion}

In the present paper we have chosen to take a discursive perspective on polite behavior by seeing it as part of the relational work inherent in all human social interaction. We use the term "relational work" rather than "facework" because human beings do not restrict themselves to forms of cooperative communication in which face-threatening is mitigated. Displays of aggression, the negotiation of conflict, the management of formal situations in which linguistic etiquette is required, friendly banter, teasing, etc. are all aspects of relational work. If we follow Goffman, individuals' faces will be assigned in accordance with the lines they are assumed to have taken in verbal interaction, implying that any individual may be allotted any number of different faces. Some forms of rela- 
tional work clearly justify face-threatening; some even aim at blatant face damage ${ }^{10}$. Depending upon the kind of verbal social behavior in which individuals engage, they will adapt their relational work to what is considered appropriate. Given that this is the case, it is not valid to refer to conflictual and aggressive behavior as inherently "impolite", "rude", or "discourteous". But neither is it valid to classify excessively formal or indirect behavior as automatically "polite", "polished" or "distinguished". Hence no utterance is inherently polite.

Relational work looks at all forms of verbal interaction in their own right. If the researcher is interested in the "polite" level of relational work, the focus should be on the discursive struggle over what constitutes appropriate/politic behavior. This will automatically include the discursive struggle over what is deemed by individuals to be polite. While we have repeatedly stressed that no utterance is inherently polite, we do claim that individuals evaluate certain utterances as polite against the background of their own habitus, or, to put it in another way, against the structures of expectation evoked within the frame of the interaction. This is where the discursive struggle over politeness occurs. This entails that researchers would be focusing on politeness1 rather than presupposing a universally valid concept of politeness 2 and then fitting their data to the theory. We take the mitigating strategies that Brown and Levinson propose in their model to be data-driven, but we consider it unfortunate that so much empirical research based on their work has simply assumed the validity of the theoretical ranking of politeness 2 in accordance with these strategies. We take the strategies themselves to belong to the study of relational work, but specifically aimed at mitigating face-threatening acts. Some of the instantiations of those strategies in real verbal interaction may indeed be perceived by participants to be "polite". By the same token, however, others may not.

Does this then mean that we should abandon what might now seem to be the elusive search for "politeness" (and mutatis mutandem "impoliteness")? Clearly not. To mix our metaphors somewhat, politeness, like beauty, is in the eye of the beholder. We maintain that the study of the discursive struggle over politeness1, judged against the background of impoliteness or politic behavior, is a fascinating field of research that merits our attention in its own right. It involves us in the close analysis of forms of verbal interaction, both oral and written, taking into account social variables that might play a significant role in this discursive struggle, e. g., educational background, social class, gender, ethnicity, etc. It is a field of research which dovetails nicely into the study of communities of practice (cf. Eckert and McConnell-Ginet 1992; Mills 2003, 2004) and the study of emergent networks (Watts 1991; Locher 2004). It is encouraging to see that more recent work in politeness research has also recognized these issues. 


\section{Appendix: Transcription Conventions (based on Du Bois et al. [1992])}

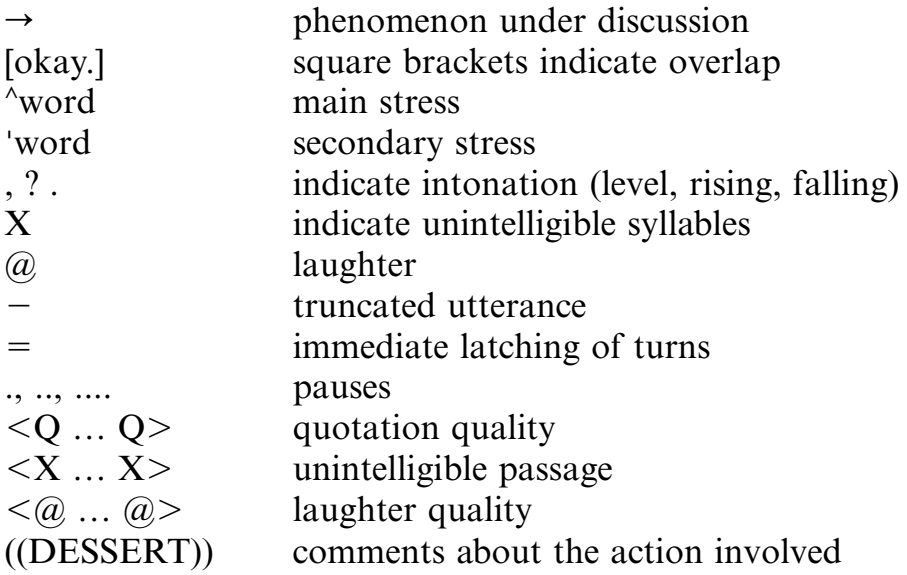

\section{Notes}

1. We would like to express our thanks to Francesca Bargiela and Karen Grainger for their perceptive comments on this paper.

2. The degree to which the reactions coincide is an issue which still needs to be investigated empirically, but it is almost certain that they will both be negative. If this were the case, reactions to impoliteness and overpoliteness might tend to converge. Within behavior which is not perceived as politic/appropriate alternative terms might be used to qualify that behavior, e.g., "rude", "sarcastic", "brash", "snide", "standoffish", etc., which, as we shall see later, are also discursively negotiated.

3. Line is defined as "a pattern of verbal and non-verbal acts by which [a participant] expresses [her/his] view of the situation and through this [her/his] evaluation of the participants" (Goffman 1967: 5).

4. See Watts (2003) and Locher (2004) for a discussion.

5. The topic of "impoliteness" has received some attention in its own right (e.g., Beebe [1995], Culpeper [1996] and Culpeper et al. [2003])

6. There is also no guarantee that the level of relational work that a speaker invests in her/his utterance will be taken up in precisely that way by the addressee (cf. the distinction between speaker- and hearer-understanding of politeness in Locher 2004: 91).

7. Our analysis is based on CA, but shares none of the skepticism with respect to cognitive, interpretative categories or sociolinguistic categories like social class, gender, ethnicity, etc., which are anathema to classical conversational analysts. We believe that a close analysis of verbal interaction is the only way to get to grips with how interactants communicate.

8. We are aware of the fact that the participants in the dinner party come from very different cultural backgrounds (for a discussion see Locher 2004: 106).

9. It is interesting that silence in extract (11) is first interpreted as impolite and then as polite by the same participant, whereas in extract (5) it is part of the expected politic behavior in this conflictual situation. This shows how multifunctional si- 
lence is in verbal interaction (cf. Jaworski 1997; Tannen and Saville-Troike 1985; Scollon and Scollon 1990).

10. Here we are thinking of the current form of public political interview (cf. Watts' analysis of an interview between David Dimbleby and Tony Blair immediately prior to the 1997 General Election [2003]), and radio or television programs in which members of the public expose themselves knowingly to outright insults.

\section{References}

Bateson, Gregory (1954). A Theory of Play and Fantasy. Steps to an Ecology of Mind. New York: Ballantine.

Beebe, Leslie M. (1995). Polite fictions: Instrumental rudeness as pragmatic competence. Georgetown University Round Table on Languages and Linguistics 1995: $154-168$.

Blum-Kulka, Shoshana (1987). Indirectness and politeness in requests: Same or different? Journal of Pragmatics 11: 131-146.

Blum-Kulka, Shoshana (1990). "You don't touch lettuce with your fingers": Parental politeness in family discourse. Journal of Pragmatics 14: 259-288.

Blum-Kulka, Shoshana, Brenda Danet, and Rimona Gherson (1985). The language of requesting in Israeli society. In Language and Social Situations, Joseph P. Forgas (ed.), 113-139. New York: Springer Verlag.

Bourdieu, Pierre (1990). The Logic of Practice. Stanford: Stanford University Press.

Brown, Penelope and Stephen Levinson (1978). Universals in language usage: Politeness phenomena. In Questions and Politeness, Esther N. Goody (ed.), 56-289. Cambridge: Cambridge University Press.

Brown, Penelope and Stephen Levinson (1987). Politeness. Some Universals in Language Usage. Cambridge: Cambridge University Press.

Culpeper, Jonathan (1996). Towards an anatomy of impoliteness. Journal of Pragmatics 25 (3): $349-367$.

Culpeper, Jonathan, Derek Bousfield, and Anne Wichmann (2003). Impoliteness revisited: with special reference to dynamic and prosodic aspects. Journal of Pragmatics 35 (10-11): 1545-1579.

Du Bois, John W., Susanna Cumming, Stephan Schütze-Coburn, and Danae Padino (eds.) (1992). Discourse Transcription. Santa Barbara Papers in Linguistics (Vol. 4), Santa Barbara: University of California.

Durkheim, Emile (1915). The Elementary Forms of the Religious Life, London: G. Allen and Unwin.

Eckert, Penelope and Sally McConnell-Ginet (1992). Think practically and act locally: Language and gender as community-based practice. Annual Review of Anthropology 21: 461-490.

Eelen, Gino (2001). A Critique of Politeness Theories. Manchester: St. Jerome Publishing.

Escandell-Vidal, Victoria (1996). Towards a cognitive approach to politeness. Language Sciences 18 (3-4): 629-650.

Fraser, Bruce (1975). The concept of politeness. Paper Presented at the 1975 NWAVE Meeting, Georgetown University.

Fraser, Bruce (1990). Perspectives on politeness. Journal of Pragmatics 14 (2): 219236.

Fraser, Bruce and William Nolen (1981). The association of deference with linguistic form. International Journal of the Sociology of Language 27: 93-109. 
Goffman, Erving (1955). On face work: An analysis of ritual elements in social interaction. Psychiatry 18: 213-231, reprinted in Goffman 1967.

Goffman, Erving (1967). Interactional Ritual: Essays on Face-to-face Behavior. Garden City, NY: Anchor Books.

Goffman, Erving (1974). Frame Analysis. An Essay on the Organization of Experience. Cambridge, MA: Harvard University Press.

Goffman, Erving (1981). Forms of Talk. Philadelphia: University of Pennsylvania Press.

Grice, H. Paul (1975). Logic and conversation. In Syntax and Semantics (Vol. 3), Peter Cole and Jerry L. Morgan (eds.), 41-58. New York: Academic Press.

$\mathrm{Gu}$, Yuego (1990). Politeness phenomena in Modern Chinese. Journal of Pragmatics 14: $237-257$.

Halliday, Michael A. K. (1978). Language as a Social Semiotic: The Social Interpretation of Language and Meaning. London: Edward Arnold.

Held, Gudrun (1995). Verbale Höflichkeit. Studien zur linguistischen Theoriebildung und empirischen Untersuchung zum Sprachverhalten französischer und italienischer Jugendlicher in Bitt- und Dankessituationen. Tübingen: Gunter Narr.

Holmes, Janet (1995). Women, Men and Politeness. London/New York: Longman.

Ide, Sachiko (1989). Formal forms of discernment: Neglected aspects of linguistic politeness. Multilingua 8 (2): 223-248.

Janney, Richard W. and Horst Arndt (1992). Intracultural versus intercultural tact. In Politeness in Language: Studies in its History, Theory and Practice, Richard J Watts, Sachiko Ide, and Konrad Ehlich (eds.), 21-41. Berlin/New York: Mouton de Gruyter.

Jaworski, Adam (ed.). (1997). Silence: Interdisciplinary Perspectives. Berlin/New York: Mouton de Gruyter.

Kasper, Gabriele (1990). Linguistic politeness: Current research issues. Journal of Pragmatics 14 (2): 193-218.

Lakoff, Robin Talmach (1973). The logic of politeness, or minding your p's and q's. Chicago Linguistics Society 9: 292-305.

Leech, Geoffrey (1983). Principles of Pragmatics. New York: Longman.

Locher, Miriam A. (2002). Markedness in politeness research. Paper presented at the Sociolinguistics Symposium 14 (SS14), Ghent, Belgium.

Locher, Miriam A. (2004). Power and Politeness in Action: Disagreements in Oral Communication. Berlin/New York: Mouton de Gruyter.

Mao, LuMing Robert (1994). Beyond politeness theory: "Face" revisited and renewed. Journal of Pragmatics 21 (5): 451-486.

Meier, A. J. (1995a). Defining politeness: Universality in appropriateness. Language Sciences 17 (4): 345-356.

Meier, A. J. (1995b). Passages of politeness. Journal of Pragmatics 24 (4): 381-392.

Mills, Sara (2003). Gender and Politeness, Cambridge: Cambridge University Press.

Mills, Sara (2004). Class, gender and politeness. Multilingua 23 (1/2): 171-190.

Schank, Roger C. and Robert P. Abelson (1977). Scripts, Plans, Goals and Understanding: An Inquiry into Human Knowledge Structures. Hillsdale, NJ: Erlbaum.

Scollon, Ron and Suzanne Wong Scollon (1990). Athabaskan-English interethnic communication. In Cultural Communication and Interactional Contact, Donal C. Carbaugh (ed.), 261-290. Hillsdale, NJ: Erlbaum.

Sifianou, Maria (1992). Politeness Phenomena in England and Greece. Oxford: Clarendon Press.

Tannen, Deborah (1993). What's in a frame?: Surface evidence for underlying expectations, In Framing in Discourse, Deborah Tannen (ed.), 14-56. Oxford: Oxford University Press. 
Tannen, Deborah and Muriel Saville-Troike (eds.) (1985). Perspectives on Silence. Norwood: Ablex Publishing Corporation.

Watts, Richard J. (1989). Relevance and relational work: Linguistic politeness as politic behavior. Multilingua 8 (2-3): 131-166.

Watts, Richard J. (1991). Power in Family Discourse. Berlin/New York: Mouton de Gruyter.

Watts, Richard J. (1992). Linguistic politeness and politic verbal behavior: Reconsidering claims for universality. In Politeness in Language: Studies in its History, Theory and Practice, Richard J. Watts, Sachiko Ide, and Konrad Ehlich (eds.), 43-69. Berlin/New York: Mouton de Gruyter.

Watts, Richard J. (1997). Silence and the acquisition of status in verbal interaction. In Silence: Interdisciplinary Perspectives, Adam Jaworski (ed.), 87-115. Berlin/ New York: Mouton de Gruyter.

Watts, Richard J. (2003). Politeness. Cambridge: Cambridge University Press.

Watts, Richard J., Sachiko Ide, and Konrad Ehlich (1992). Introduction. In Politeness in Language: Studies in its History, Theory and Practice, Richard J Watts, Sachiko Ide, and Konrad Ehlich (eds.), 1-17. Berlin/New York: Mouton de Gruyter. 